\title{
Persistent diastolic dysfunction despite successful long-term octreotide treatment in acromegaly
}

\author{
S W van Thiel, J J Bax ${ }^{1}$, N R Biermasz, E R Holman ${ }^{1}$, D Poldermans ${ }^{1}$, F Roelfsema, H J Lamb ${ }^{1}$, E E van der Wall ${ }^{1}$, \\ J W A Smit, J A Romijn and A M Pereira \\ Departments of Endocrinology and Metabolism and ${ }^{1}$ Cardiology, Leiden University Medical Center, PO Box 9600, 2300 RC Leiden, The Netherlands \\ (Correspondence should be addressed to AM Pereira, Email: A.M.Pereira@lumc.nl)
}

\begin{abstract}
Introduction: This study was designed to evaluate potential reversibility of left-ventricular (LV) dysfunction in patients with acromegaly following long-term control of disease. It is unknown whether the cardiac changes induced by acromegaly can be reversed completely by long-term strict control of growth hormone excess by octreotide.

Patients and methods: We compared LV systolic and diastolic function in inactive patients with acromegaly $(n=22)$, who were divided into patients with long-term control by octreotide $(n=14)$ and patients with long-term cure by surgery/radiotherapy $(n=8)$. We also assessed these parameters in patients with active acromegaly $(n=17)$.

Results: In patients with active acromegaly, systolic function at rest was decreased by $18 \%(P<0.01)$, LV mass index increased by 40\% $(P<0.04)$ and isovolumetric relaxation time increased by $19 \%$ $(P<0.01)$, compared with patients with inactive acromegaly. These parameters were not different between well-controlled and cured patients. Using tissue Doppler imaging, the ratio between early and late diastolic velocity ( $\mathrm{E}^{\prime} / \mathrm{A}^{\prime}$ ratio) was decreased in active, compared with inactive acromegaly $(0.75 \pm 0.07$ versus $1.24 \pm 0.15 ; P<0.01)$. This $\mathrm{E}^{\prime} / \mathrm{A}^{\prime}$ ratio was considerably higher in cured, compared with octreotide-treated, patients $(1.75 \pm 0.41$ versus $1.05 \pm 0.1 ; P<0.01)$.

Conclusion: Diastolic function is persistently and significantly more impaired in acromegalic patients with long-term control by octreotide than in surgically cured patients, which points to biological effects of subtle abnormalities in growth hormone secretion. Criteria for strict biochemical control of acromegaly should thus be reconsidered.
\end{abstract}

European Journal of Endocrinology 153 231-238

\section{Introduction}

Prolonged growth hormone $(\mathrm{GH})$ excess can induce myocardial changes $(1-4)$. These changes include leftventricular (LV) hypertrophy, diastolic dysfunction, systolic dysfunction during exercise, arrhythmias and heart failure (5). Recently, regurgitant valve disease has also been documented in acromegalic patients $(6,7)$. The incidence and severity of these cardiac changes are related to disease activity and disease duration. LV hypertrophy appears to be an early consequence of GH excess (8-11), whereas arrhythmias and valvular disease are associated with long-standing disease $(6,12)$.

Adequate treatment of GH excess can arrest, and even reverse, several of these cardiac changes. A total of 19 studies evaluated the effect of long-term suppression - that is, 6 months or more - of GH excess on cardiac function, summarized in Table 1. From these studies it is evident that LV mass decreases in association with improved systolic and diastolic function in patients, in whom GH excess is well-controlled. Nonetheless, it is not entirely clear to which extent long-term successful biochemical control of $\mathrm{GH}$ excess can reverse cardiac function. For instance, although octreotide treatment improved LV ejection fraction (LVEF), measured after 1 year of treatment, LVEF did not normalize completely (8). Only one study compared cardiac function 5 years after normalization of $\mathrm{GH} /$ insulin-like growth factor I (IGF-I) excess and compared patients with controlled disease and patients with cured disease. There were no differences in cardiac function, assessed by radionuclide ventriculography, between patients who were well controlled by octreotide and those cured by surgery (13). However, all non-invasive techniques have major pitfalls in so far as they cannot measure LV pressures directly.

Recent data raise questions about whether the currently accepted definition of biochemical control of $\mathrm{GH}$ excess - that is, $\mathrm{GH}$ levels $<2.5 \mu \mathrm{g} / \mathrm{l}$ and normal ageand sex-related IGF-I levels - can be equated with normalization of all aspects of $\mathrm{GH}$ secretion in all 
Table 1 The effect of long-term suppression of GH excess (6 months or more) on cardiac function in acromegaly.

\begin{tabular}{|c|c|c|c|c|c|c|}
\hline Study & $\begin{array}{l}\text { No. of } \\
\text { patients }\end{array}$ & $\begin{array}{l}\text { Definition of cure/well-controlled } \\
\text { disease }\end{array}$ & $\begin{array}{l}\text { No. of patients achieving } \\
\text { treatment goals }(\%)\end{array}$ & Method of assessment & $\begin{array}{l}\text { Duration of } \\
\text { treatment }\end{array}$ & Effect on cardiac performance \\
\hline 26 & 9 & Decrease of $\mathrm{GH}$ by $62 \%$ & Not defined & $2 \mathrm{D}$ echo & 1 year & $\begin{array}{l}\text { Systolic function at rest: } \uparrow \text { LV mass } \downarrow \text { (but still } \\
\text { above ref values) Diastolic function: not assessed }\end{array}$ \\
\hline 35 & 3 & Mean GH $5.2 \mu \mathrm{g} / \mathrm{I}$ Normal IGF-I & Not defined & Right heart cath & $2-3$ years & Cardiac index: normalization $\downarrow$ Filling pressures \\
\hline 29 & 5 & $\begin{array}{l}24 \text { GH profiles: }<5 \mu \mathrm{g} / \mathrm{IGF}-\mathrm{I} \text { not } \\
\text { measured }\end{array}$ & $4(80 \%)$ & 2D echo/Doppler & 6 months & $\begin{array}{l}\text { Systolic function at rest: no change LV mass } \downarrow \\
\uparrow \text { Early diastolic transmitral flow velocity }\end{array}$ \\
\hline 25 & 11 & $\begin{array}{l}\text { Mean GH } 4.6 \mu \mathrm{g} / \mathrm{l} \text { Mean IGF-I } \\
235 \mu \mathrm{g} / \mathrm{l}\end{array}$ & $11(100 \%)$ & 2D echo/Doppler & 6 months & $\begin{array}{l}\text { Systolic function at rest: no change LV mass } \downarrow \\
\uparrow \text { Diastolic filling indices }\end{array}$ \\
\hline 18 & 22 & $\begin{array}{l}\text { Mean GH }<5 \mu \mathrm{g} / / \text { OGTT nadir }<1 \\
\mu \mathrm{g} / \mathrm{IGF}-\mathrm{I}<450 \mu \mathrm{g} / \mathrm{I}\end{array}$ & $11(50 \%)$ & 2D echo/Doppler & 10 years & $\begin{array}{l}\text { Systolic function at rest: } \uparrow \text { LV mass } \downarrow \text { Diastolic } \\
\text { function: not assessed }\end{array}$ \\
\hline 27 & 6 & Mean GH $4 \mu \mathrm{g} / \mathrm{l}$ IGF-I not measured & None & 2D echo/max treadmill test & 6 months & $\begin{array}{l}\text { Systolic function at rest: no change LV mass } \downarrow \\
\text { Diastolic function: not assessed }\end{array}$ \\
\hline 24 & 30 & $\begin{array}{l}\text { Mean GH }<2.51 \mu \mathrm{g} / \mathrm{l} \text { Nadir GH } \\
<1 \mu \mathrm{g} / \mathrm{l} \text { Normal IGF-I }\end{array}$ & $13(43 \%)$ & $\begin{array}{l}\text { Gated blood-pool } \\
\text { scintigrafy }\end{array}$ & 1 year & $\begin{array}{l}\text { Inactive: } \uparrow \text { LVEF, but no normalization; no } \\
\text { changes in diastolic filling Persistent active: } \\
\downarrow \text { cardiac performance }\end{array}$ \\
\hline 23 & 13 & $\begin{array}{l}\text { Not defined (mean GH and IGF-I not } \\
\text { normalized) }\end{array}$ & Not available & 2D echo/Doppler & 18 months & $\begin{array}{l}\text { Systolic function at rest: no change LV mass } \downarrow \\
\text { Diastolic function: } \uparrow\end{array}$ \\
\hline 36 & 13 & $\mathrm{GH}<2.5 \mu \mathrm{g} / \mathrm{l}$ and/or normal IGF-I & $8(62 \%)$ & 2D echo/Doppler & 1 year & $\begin{array}{l}\text { Systolic function at rest: no change LV mass } \downarrow \\
\downarrow \text { IRT and A }\end{array}$ \\
\hline 21 & 15 & $\begin{array}{l}\text { GH }<3.5 \mu \mathrm{g} / / / \text { nadir }<1.5 \mu \mathrm{g} / \mathrm{l} \text { Normal } \\
\text { IGF-I }\end{array}$ & $9(60 \%)$ & $\begin{array}{l}\text { 2D echo/Doppler/gated } \\
\text { blood-pool scintigrafy }\end{array}$ & 6 months & $\begin{array}{l}\text { Systolic function: LVEF rest/exercise } \uparrow \\
\text { LV mass } \downarrow \text { Diastolic function } \uparrow\end{array}$ \\
\hline 13 & 18 & $\begin{array}{l}\text { Fasting GH }<2.5 \mu \mathrm{g} / \mathrm{l} \text {, or }<1 \mu \mathrm{g} / \mathrm{l} \\
\text { after OGTT and normal IGF-I }\end{array}$ & $\begin{array}{l}13(72 \%) \text { ( } 7 \text { cured, } \\
6 \text { well-controlled) }\end{array}$ & gated blood-pool scintigrafy & 5 years & $\begin{array}{l}\text { Controlled: LVEF during exercise } \uparrow \text { Diastolic } \\
\text { function: no change }\end{array}$ \\
\hline 37 & 30 & $\begin{array}{l}\text { OGTT GH nadir }<0.75 \mu \mathrm{g} / \mathrm{l} \text { Normal } \\
\text { IGF-I }\end{array}$ & $15(50 \%)$ & 2D echo and Doppler & 6 months & $\begin{array}{l}\text { Systolic function at rest: no change LV mass } \downarrow \\
\text { Diastolic function } \uparrow\end{array}$ \\
\hline 38 & 32 & $\begin{array}{l}\text { OGGT GH nadir }<1 \mu \mathrm{g} / \mathrm{l} \text { and normal } \\
\text { IGF-I; Well-controlled: normal IGF-I }\end{array}$ & 19 (59\%) & 2D echo/Doppler and TDI & $\begin{array}{l}\text { Not } \\
\text { documented }\end{array}$ & $\begin{array}{l}\text { Systolic function at rest: } \uparrow \text { Diastolic function: no } \\
\text { difference between cured/well-controlled and } \\
\text { controls }\end{array}$ \\
\hline 39 & 15 & $\begin{array}{l}\text { Basal GH }<5 \mu \mathrm{g} / \mathrm{l} \text { OGGT GH nadir } \\
<2 \mu \mathrm{g} / \mathrm{l} \text { normal IGF-I }\end{array}$ & $\begin{array}{l}15(100 \% \\
\text { preselected })\end{array}$ & 2D echo and Doppler & 2.7 years & LV mass $\downarrow$ Diastolic function $\uparrow$ \\
\hline 9 & 25 & Fasting GH $<2.5 \mu \mathrm{g} / \mathrm{l}$ normal IGF-I & $13(53 \%)$ & $\begin{array}{l}\text { 2D echo/Doppler and gated } \\
\text { blood-pool scintigrafy }\end{array}$ & 6 months & $\begin{array}{l}\text { Systolic function: } \uparrow \text { (normalization of } \\
\text { LVEF peak exercise) LV mass } \downarrow\end{array}$ \\
\hline 40 & 19 & Fasting GH $<2.5 \mu \mathrm{g} / \mathrm{l}$ normal IGF-I & $11(58 \%)$ & 2D echo and Doppler & 6 onths & $\begin{array}{l}\text { Systolic function at rest: unchanged LV mass } \downarrow \\
\text { Diastolic function: } \uparrow\end{array}$ \\
\hline 22 & 8 & Fasting GH $<2.5 \mu \mathrm{g} / \mathrm{l}$ normal IGF-I & $1(13 \%)$ & 2D echo & 6 months & $\begin{array}{l}\text { Systolic function: } \uparrow \text { LV mass } \downarrow \text { Diastolic function: } \\
\text { not assessed }\end{array}$ \\
\hline 41 & 22 & Mean GH $<2.5 \mu \mathrm{g} / \mathrm{l}$ normal IGF-I & $\begin{array}{l}22(100 \% \\
\text { preselected })\end{array}$ & $\begin{array}{l}\text { 2D echo/Doppler and gated } \\
\text { blood-pool scintigrafy }\end{array}$ & 1 year & $\begin{array}{l}\text { Systolic function: } \uparrow \text { (LVEF at peak exercise } \\
\text { normalized in } 80 \% \text { young } / 50 \% \text { middle age patients } \\
\text { LV mass } \downarrow \text { Diastolic function: no change }\end{array}$ \\
\hline 42 & 16 & Mean $\mathrm{GH}<2.5 \mu \mathrm{g} / \mathrm{I}$ normal IGF-I & $6(38 \%)$ & $\begin{array}{l}2 \mathrm{D} \text { echo/Doppler and } \\
\text { ultrasonic tissue } \\
\text { characterization }\end{array}$ & $6-9$ months & $\begin{array}{l}\text { Systolic/diastolic function: no change LV mass } \downarrow \\
\text { Normalization of heart collagen content }\end{array}$ \\
\hline $\begin{array}{l}\text { Present } \\
\text { series }\end{array}$ & 39 & $\begin{array}{l}\text { Mean GH }<2.5 \mu \mathrm{g} / \mathrm{l} \text {, or OGTT GH } \\
\text { nadir }<0.5 \mu \mathrm{g} / \mathrm{l} \text { normal IGF-I }\end{array}$ & $22(56 \%)$ & 2D echo/Doppler and TDI & $\begin{array}{l}\text { Median } 6 \\
\text { years (range } \\
1-14)\end{array}$ & $\begin{array}{l}\text { LV mass } \downarrow \text { Systolic function at rest: } \uparrow \text { Diastolic } \\
\text { function: conventional Doppler: } \uparrow \text { TDI: } \uparrow \text {, but } \\
\text { persistently impaired in well-controlled Disease }\end{array}$ \\
\hline
\end{tabular}

2D echo, two-dimensional echocardiography; IRT, isovolumetric relaxation time; A, late transmutral peak velocity; OGTT, oral glucose tolerance test. 
circumstances. First, we showed (14), that long-term treatment of patients with active acromegaly with somatostatin analogues does not normalize 24-h GH secretion, even though all these patients fulfilled the above-mentioned criteria for strict biochemical control. In contrast, 24-h GH secretion in acromegalic patients cured by transsphenoidal surgery was not different from the values in matched controls. Second, discordant results between IGF-I and GH concentrations have been reported in a significant proportion of newly diagnosed acromegalic patients $(15,16)$. Because somatostatin analogues do not completely normalize $\mathrm{GH}$ secretion, it is possible that treatment with these analogues aiming at strict biochemical control of GH excess may not normalize cardiac abnormalities to the extent of the effects of curation by transsphenoidal surgery.

Therefore, we investigated whether there were differences in cardiac parameters between patients with long-term 'control' of GH excess by treatment with octreotide and patients cured by surgery, using a group of patients with active acromegaly as a reference group. We used echocardiography including tissue Doppler imaging (TDI), which allows for a detailed and quantitative assessment of cardiac parameters including diastolic and systolic function (17).

\section{Materials and methods}

\section{Patients}

We studied 39 consecutive patients with acromegaly (19 men) referred from the outpatient clinic of the Leiden University Medical Center, Leiden, The Netherlands (Table 2). The mean age of the patients was 56 years (range 20-83 years). The diagnosis of acromegaly was based on the characteristic clinical features and confirmed by insufficient suppression of $\mathrm{GH}$ during a glucose tolerance test (GH nadir below $0.5 \mu \mathrm{g} / \mathrm{l})$, and the presence of a pituitary adenoma on radiological imaging.

We classified patients according to the presence or absence of GH excess as having active or inactive acromegaly, respectively The patients with inactive acromegaly consisted of two groups: (1) well-controlled patients $(n=14)$ : mean fasting $\mathrm{GH}$ concentration (measured for $3 \mathrm{~h}$ with an interval of $30 \mathrm{~min}$ ) of $<2.5 \mu \mathrm{g} / \mathrm{l}$, and normal age- and gender-adjusted IGF-I concentrations during treatment with depot octreotide acetate; (2) patients cured after surgery $(n=8)$ : no treatment with depot octreotide acetate, GH nadir after oral glucose loading $(75 \mathrm{~g})$ of $<0.5 \mu \mathrm{g} / \mathrm{l}$, and normal ageand gender-adjusted IGF-I concentrations. Pre-therapy disease severity was not different between the two groups. The patients with active acromegaly consisted of two other groups: (3) untreated patients $(n=8)$ : no treatment to reduce GH excess had yet been instituted; (4) uncontrolled patients $(n=9)$ : mean fasting $\mathrm{GH}$ concentrations (measured every $30 \mathrm{~min}$ for $3 \mathrm{~h}$ ) of $>2.5 \mu \mathrm{g} / \mathrm{l}$, and/or elevated age- and sex-adjusted IGF-I concentrations despite treatment with maximal dosages of depot octreotide acetate ( $30 \mathrm{mg}$ i.m. every 3 weeks). Cardiac parameters (see below) were analysed in groups of cured and controlled acromegaly, using untreated and uncontrolled patients as reference/control groups. None of the patients had haemodynamic instability, previous myocardial infarction, thyrotoxicosis, rheumatic fever, endocarditis, anorexigen use or connective-tissue disease. If hypertension was present (blood pressure $>140 / 95 \mathrm{mmHg}$ ), medication was prescribed to reduce blood pressure to values of

Table 2 Baseline characteristics.

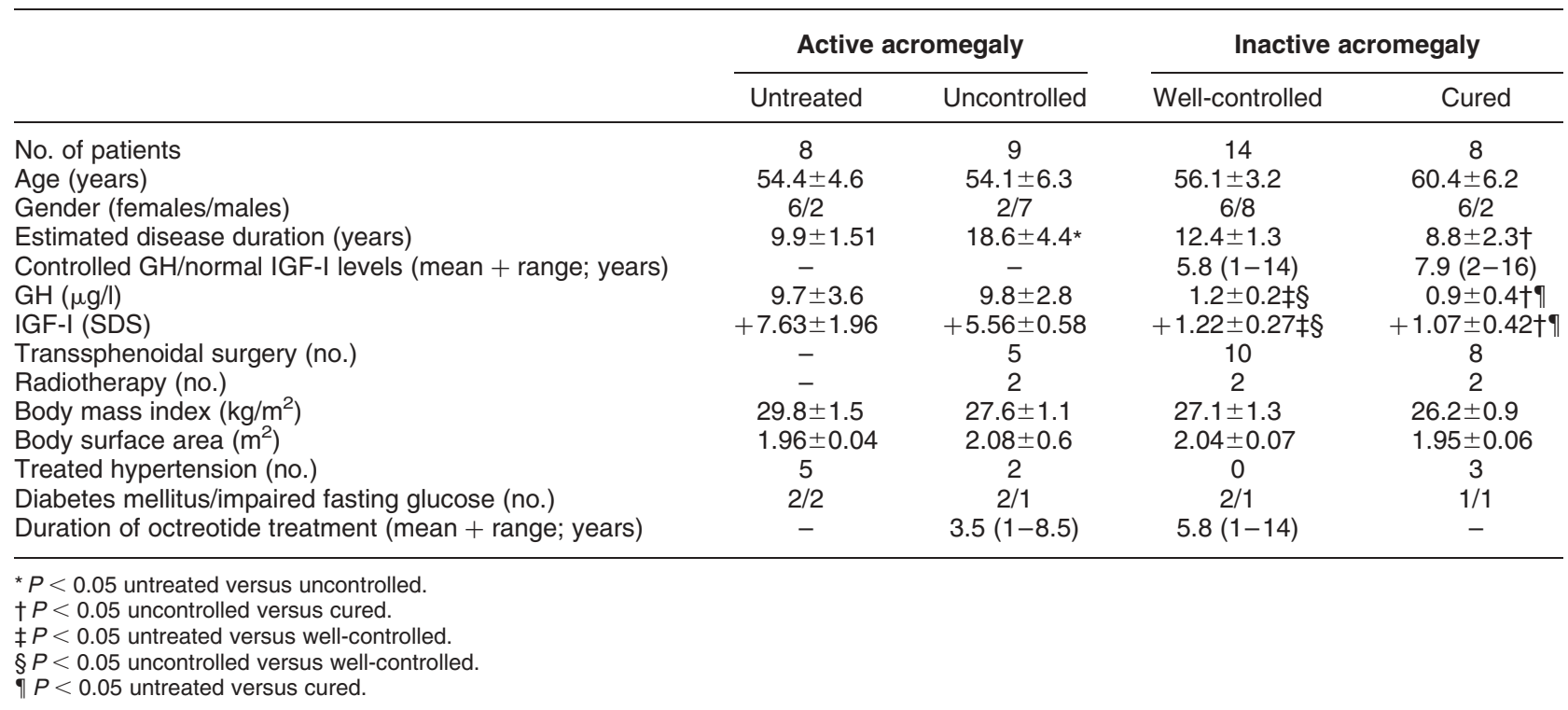


$<140 / 90 \mathrm{mmHg}$. All subjects had a normal blood pressure for at least 1 year prior to the study. Glucose tolerance was assessed according to the 1997 American Diabetes Association (ADA) criteria: (i) normal was defined as fasting plasma glucose below $6.1 \mathrm{mM}$; (ii) impaired fasting glucose was defined as between 6.1 and $7.0 \mathrm{mM}$; (iii) diabetes mellitus, defined as fasting plasma glucose of $\geqq 7.0 \mathrm{mM}$. None of the female patients were pregnant during the 9 months following echocardiography. The duration of disease was defined by the onset of clinical symptoms related to GH excess (carpal tunnel syndrome, sleep apnoea and arthralgias), and by careful comparison of old photographs. The end of disease duration was defined as the time of successful treatment (that is, cured or well-controlled disease). The duration of wellcontrolled disease or cure was defined as the time of successful medical treatment and/or transsphenoidal surgery with or without adjuvant radiotherapy, until the time of echocardiography.

The local institutional ethics committee approved the study, and written informed consent was obtained from all subjects.

\section{Echocardiography, data acquisition}

Echocardiography was performed with the patients in the left lateral decubitus position using a commercially available system (Vingmed system FiVe/Vivid-7; General Electric - Vingmed, Milwaukee, WI, USA). Standard parasternal (long and short axis) and apical views (two-, four- and five-chamber) were obtained. Standard continuous-wave and pulsed-wave Doppler examinations were performed. M-mode images were obtained from the parasternal long-axis views for quantitative assessment of $\mathrm{LV}$ dimensions, fractional shortening (FS) and $\operatorname{LVEF}(10,18)$. LV mass was calculated by the cube formula, and using the correction formula proposed by Devereux et al. (19; see also 20):
$\mathrm{LV}$ mass $=0.8 \times\{1.04(\mathrm{LVEDD}$ diameter $+\mathrm{PWD}$

$$
\left.+ \text { IVSD })^{3}+\operatorname{LVEDD}^{3}\right\}+0.6
$$

LVEDD, PWD and IVSD are defined in Table 3 (below). LV mass index (LVMI) was corrected for body surface area. LV hypertrophy was defined as a LVMI value above $135 \mathrm{~g} / \mathrm{m}^{2}$ for men and $110 \mathrm{~g} / \mathrm{m}^{2}$ for women. Systolic function was evaluated by measurements of FS and LVEF. The following parameters of diastolic function were measured: diastolic transmitral peak velocities ( $\mathrm{E}$ and $\mathrm{A}$ wave), the $\mathrm{E} / \mathrm{A}$ ratio, the isovolumetric relaxation time (IVRT) and the E-deceleration time. Quantitative diastolic data were derived from TDI analysis. For TDI analysis, the digital cineloops were analysed using commercial software (Echopac 6.1; General Electric - Vingmed). The sample volume $\left(4 \mathrm{~mm}^{3}\right)$ was placed in the $\mathrm{LV}$ basal portion of the septum (using the four-chamber images). The following parameters (mean values calculated from three consecutive beats) were derived: early diastolic velocity $\left(\mathrm{E}^{\prime}\right)$, late diastolic velocity $\left(\mathrm{A}^{\prime}\right)$ and the $\mathrm{E}^{\prime} / \mathrm{A}^{\prime}$ ratio. All echocardiographic examinations and analyses were performed by a single observer, blinded for treatment modalities.

\section{Hormone assays}

$\mathrm{GH}$ concentrations were quantitated in duplicate using a sensitive time-resolved immunofluorescence assay (Wallac, Turku, Finland), specific for $22 \mathrm{kDa} \mathrm{GH}$ protein, and calibrated against WHO IRP 80/505. The detection limit was $0.012 \mu \mathrm{g} / \mathrm{l}$. Intra-assay coefficients of variation were $1.6-8.4 \%$ in the $\mathrm{GH}$ range $0.012-18 \mu \mathrm{g} / \mathrm{l}$. The total serum IGF-I concentration was determined by RIA after extraction and purification on ODS-silica columns (Incstar Corp., Stillwater, MN, USA). The intra- and inter-assay coefficients of variation were less than $11 \%$. The detection limit was

Table 3 LV dimensions and systolic function at rest.

\begin{tabular}{|c|c|c|c|c|}
\hline & \multicolumn{2}{|c|}{ Active acromegaly } & \multicolumn{2}{|c|}{ Inactive acromegaly } \\
\hline & Untreated & Uncontrolled & Well-controlled & Cured \\
\hline LVEDD (mm) & $49.8 \pm 2.5$ & $57.9 \pm 3.8$ & $53.6 \pm 1.7$ & $50.4 \pm 3.5$ \\
\hline LVESD (mm) & $34.4 \pm 2.7$ & $40.2 \pm 4.1$ & $34.1 \pm 1.9$ & $32.6 \pm 2.7$ \\
\hline IVSD (mm) & $13.1 \pm 1.6$ & $13.8 \pm 1.1$ & $9.6 \pm 0.5^{\star} \dagger$ & $10.6 \pm 1.3$ \\
\hline PWD (mm) & $11.0 \pm 0.9$ & $10.3 \pm 0.8$ & $9.7 \pm 0.5$ & $9.4 \pm 0.5$ \\
\hline LVM (g) & $250 \pm 48$ & $314 \pm 57$ & $201 \pm 20 \dagger$ & $199 \pm 43$ \\
\hline LVMI $\left(\mathrm{g} / \mathrm{m}^{2}\right)$ & $126.0 \pm 22.5$ & $153 \pm 27.7$ & $99.6 \pm 9.5 \dagger$ & $100.3 \pm 19.5$ \\
\hline FS (\%) & $30.9 \pm 2.5$ & $29.9 \pm 2.6$ & $36.8 \pm 1.7 \dagger$ & $37.4 \pm 1.4 \ddagger$ \\
\hline LVEF (\%) & $57.8 \pm 3.8$ & $59.7 \pm 2.81$ & $72.4 \pm 2.6^{\star} \dagger$ & $73 \pm 1.8 \mp \S$ \\
\hline
\end{tabular}

LVEDD, LV end-diastolic diameter; LVESD, LV end-systolic diameter; IVSD, inter-ventricular septum diameter; PWD, posterior wall diameter; LVM, LV mass; LVMI, LVM/body surface area.

${ }^{*} P<0.05$ untreated versus well-controlled.

$\dagger P<0.05$ uncontrolled versus well-controlled.

$\ddagger P<0.05$ uncontrolled versus cured.

$\S P<0.05$ untreated versus cured. 
$1.5 \mathrm{nM}$. Age-related normal data were determined in the same laboratory. IGF-I was also expressed as a SDS from age-related normal levels.

\section{Statistical analysis}

Univariate analysis of variance was performed to compare groups, and the Bonferroni multiple comparison as a post hoc test. Linear-by-linear association was performed to investigate a trend for having untreated, uncontrolled, well-controlled or cured disease with an $\mathrm{E}^{\prime} / \mathrm{A}^{\prime}$ ratio of $<1$. Data are expressed as means \pm s.E.M. SPSS software version 11.0 (SPSS, Chicago, IL, USA) was used. Differences were considered statistically significant at the $P<0.05$ level.

\section{Results}

\section{Clinical characteristics}

The clinical characteristics are provided in Table 2. GH and IGF-I concentrations were much higher in patients with active acromegaly, compared with the values obtained in patients with inactive acromegaly, reflecting the different inclusion criteria for the different groups. However, there were no differences in GH/IGF-I levels between untreated and uncontrolled patients, nor between well-controlled and cured patients. The duration of controlled GH/IGF-I levels was not different between well-controlled patients and cured patients (mean 5.8 years, range 1-14 years, versus mean 7.9 years, range $2-16$ years, respectively; not significant).

\section{$\mathrm{LV}$ dimensions and systolic function at rest}

LV dimensions were not different between patients with active and inactive acromegaly (Table 3). However, LVMI was above the normal range and $40 \%$ higher in patients with active acromegaly, compared with patients with inactive acromegaly $(140 \pm 17.9$ versus $99.8 \pm 8.8 \mathrm{~g} / \mathrm{m}^{2}$, respectively; $\left.P<0.04\right)$. LVMI was within the normal range and not different between well-controlled and cured patients.

Systolic function at rest, reflected by FS and LVEF, was decreased by $18-19 \%$ in patients with active acromegaly, compared with patients with inactive acromegaly. FS was $30.3 \pm 1.8$ versus $37.0 \pm 1.2 \%$, respectively $(P<0.01)$ and $\mathrm{LVEF}$ was 58.8 \pm 2.3 versus $72.6 \pm 1.8 \%$, respectively $(P<0.01)$. However, FS and LVEF were not different between well-controlled and cured patients.

\section{Diastolic function}

There were no statistically significant differences in diastolic transmural peak velocities (E and A waves) between patients with active and inactive acromegaly. The IVRT was increased by $19 \%$ in patients with active acromegaly compared with patients with inactive acromegaly (109.7 \pm 4.0 versus $88.7 \pm 2.5 \mathrm{~ms} ; \quad P<0.01)$. However, there were no significant differences between untreated and uncontrolled patients, nor between well-controlled and cured patients.

Diastolic function, assessed by TDI (Fig. 1), showed that the early diastolic velocity $\left(\mathrm{E}^{\prime}\right)$ was significantly
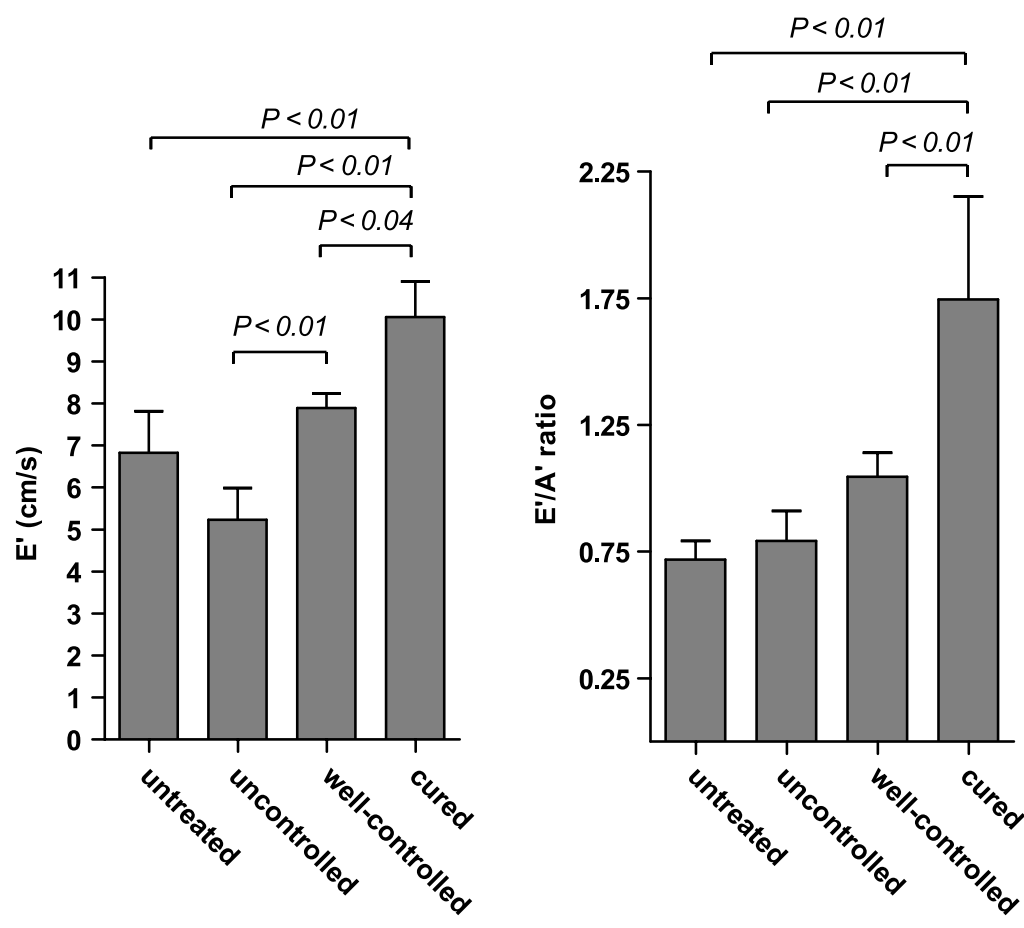

Figure 1 Diastolic function in patients with acromegaly as assessed by TDI. 
higher in cured patients as compared with the other patient groups (Table 4 and Fig. 1). A significant difference in $\mathrm{E}^{\prime}$ was also noted between uncontrolled and well-controlled patients: $\mathrm{E}^{\prime}$ was higher in well-controlled patients $(P<0.01)$, but was still significantly lower than in those who were cured of disease $(P<0.04)$. The $\mathrm{E}^{\prime} / \mathrm{A}^{\prime}$ ratio was considerably decreased in patients with active acromegaly compared with patients with inactive acromegaly $(0.75 \pm 0.07$ versus $1.24 \pm 0.15 ; P<0.01)$. In cured patients, the $\mathrm{E}^{\prime} / \mathrm{A}^{\prime}$ ratio was significantly higher when compared with well-controlled patients (1.75 \pm 0.41 versus $1.05 \pm 0.1$, respectively; $P<0.01$ ). Remarkably, the $\mathrm{E}^{\prime} / \mathrm{A}^{\prime}$ ratio was $<1$ in all untreated patients and in $75 \%$ of uncontrolled patients. The $\mathrm{E}^{\prime} / \mathrm{A}^{\prime}$ ratio was $<1$ in $50 \%$ of the well-controlled patients compared with only $12 \%$ of the cured patients $(P=0.003)$.

\section{Discussion}

The present study demonstrates that surgically cured acromegalic patients had significantly improved cardiac function compared with those in long-term remission by octreotide treatment. During long-term follow up, diastolic function was significantly more impaired in the patients on medication despite optimal treatment with somatostatin analogues, according to strict criteria of GH/IGF-I concentrations.

The question arises as to whether other factors may have affected our observations, other than these related to the disease activity of acromegaly. First, the duration of GH excess is a determinant of cardiac abnormalities (6, 8). The group characterized as having active disease had a longer duration of disease than the cured patients, which will have affected cardiac function. However, there were no significant differences in disease duration between well-controlled and cured patients. Second, the degree of $\mathrm{GH}$ excess is a determinant of cardiac abnormalities. However, there were no differences in
GH levels obtained over several hours or IGF-I levels between well-controlled and cured patients. Third, there were no differences in duration of strict control between both groups. Fourth, there were no differences in body mass index or age, which may have affected our conclusions. Fifth, treated hypertension, which may have induced diastolic dysfunction, was present in $38 \%(3 / 8)$ of the cured patients but in none of the wellcontrolled group. Moreover, all patients with treated hypertension had a blood pressure of $<140 / 90 \mathrm{mmHg}$ during the year prior to the study. Finally, the prevalence of diabetes mellitus and impaired glucose tolerance was not different between cured and well-controlled patients (25 versus $21 \%$, respectively). Therefore, our observations are not affected by differences in blood pressure or carbohydrate metabolism. Based on these arguments, we feel that it is unlikely that our interpretation of the data is confounded by parameters other than those related to disease activity of acromegaly. However, we cannot exclude the possibility that the persistent cardiac impairment could be due to still-unknown factors other than GH hypersecretion, like asymptomatic ischaemia.

Treatment of GH excess favourably affects cardiac function and mass. To our knowledge, a total of 19 studies involving 312 acromegalic patients have been published, which have assessed the effect of treatment on cardiac function (Table 1). Treatment of GH excess decreased LV mass and improved diastolic function invariably, whereas systolic function at rest remained unchanged in most of the studies. Our data are in accordance with these conclusions from the other studies. Of the 312 patients, $53 \%$ (166 patients) achieved treatment goals, defined by normalization of IGF-I and fasting GH levels below $2.5 \mu \mathrm{g} / \mathrm{l}$ or glucose-suppressed $\mathrm{GH}$ levels below $1 \mu \mathrm{g} / \mathrm{l}$. The majority of these patients, $120 / 166(72 \%)$, were well-controlled by somatostatin analogue treatment. In these 120 patients, LV mass normalized and cardiac function improved. This was reflected mainly by an increase in LVEF during exercise (21-29), a feature that has already

Table 4 Diastolic function as assessed by echocardiography and TDI.

\begin{tabular}{|c|c|c|c|c|}
\hline & \multicolumn{2}{|c|}{ Active acromegaly } & \multicolumn{2}{|c|}{ Inactive acromegaly } \\
\hline & Untreated & Uncontrolled & Well-controlled & Cured \\
\hline $\mathrm{E}(\mathrm{mm} / \mathrm{s})$ & $55.5 \pm 3.9$ & $56.4 \pm 6.8$ & $52.7 \pm 3.3$ & $65 \pm 5.8$ \\
\hline $\mathrm{A}(\mathrm{mm} / \mathrm{s})$ & $59.4 \pm 4.9$ & $67.4 \pm 5.8$ & $55.7 \pm 4.7$ & $55.8 \pm 3.7$ \\
\hline E/A ratio & $1.0 \pm 0.2$ & $0.83 \pm 0.5$ & $1.01 \pm 0.1$ & $1.18 \pm 0.1$ \\
\hline Edec (ms) & $171 \pm 10.2$ & $180.3 \pm 19.4$ & $180.1 \pm 17.2$ & $163.8 \pm 12$ \\
\hline IVRT(ms) & $109.9 \pm 3.0$ & $109.6 \pm 7.3$ & $90.6 \pm 3.0 * \dagger$ & $84.2 \pm 4.1 \neq \S$ \\
\hline $\mathrm{E}^{\prime}(\mathrm{cm} / \mathrm{s})$ & $6.83 \pm 0.99$ & $5.23 \pm 0.76$ & $7.89 \pm 0.34 \dagger$ & $10.06 \pm 0.84 \neq \S 1$ \\
\hline $\mathrm{A}^{\prime}(\mathrm{cm} / \mathrm{s})$ & $9.38 \pm 1.21$ & $6.71 \pm 0.36^{\star *}$ & $8.00 \pm 0.52$ & $6.6 \pm 0.93 \ddagger$ \\
\hline$E^{\prime} / A^{\prime}$ ratio & $0.72 \pm 0.07$ & $0.79 \pm 0.19$ & $1.05 \pm 0.09$ & $1.75 \pm 0.41 \neq \S$ \\
\hline
\end{tabular}

$E$, early transmitral peak velocity; A, late transmitral peak velocity; Edec, E-deceleration time; $E^{\prime}$, early diastolic velocity; $A^{\prime}$, late diastolic velocity.

${ }^{*} P<0.05$ untreated versus well-controlled.

$\dagger P<0.05$ uncontrolled versus well-controlled.

$\ddagger P<0.05$ untreated versus cured.

$\S P<0.05$ uncontrolled versus cured.

If $P<0.05$ well-controlled versus cured

** $P<0.05$ untreated versus uncontrolled. 
been observed within a few months of treatment with somatostatin analogues. Prolonged suppression of basal or glucose-suppressed GH levels to values below 2.5 or $1 \mu \mathrm{g} / \mathrm{l}$, respectively, in combination with normalization of plasma IGF-I levels for at least 1 year, resulted in significant improvement, but not complete normalization, of LVEF either at rest or at peak exercise without significant changes in diastolic filling (24). These data suggest that prolonged suppression of circulating GH and IGF-I levels normalizes systolic cardiac performance. 46 of the 166 patients $(27 \%)$ with inactive acromegaly were biochemically cured by surgery and/or radiotherapy and were not treated with somatostatin analogues. Hradec et al. (18) demonstrated a clear beneficial effect of long-term cure on LVMI, but diastolic function was not assessed in that particular study. This beneficial effect of cure of GH excess on LVMI was confirmed in other studies, with a concomitant improvement, but not normalization, in diastolic function $(28,29)$. The biochemical criteria used in the studies on cardiac function in acromegaly are based on other studies, which have shown that these criteria are associated with a reversal of the increased risk for malignancies and mortality, associated with GH excess $(18,30,31)$. However, it is unknown whether biochemical control of GH/IGF-I excess, according to these criteria, is also sufficient to normalize other GH-related morbidity, like acromegalic cardiomyopathy.

The findings in the current study, in patients with long-term control of GH excess (median of 6 years), demonstrated that two independent parameters of diastolic function, the $\mathrm{E}^{\prime} / \mathrm{A}^{\prime}$ ratio and the IVRT, improved significantly, indicating ameliorated relaxation and decreased stiffness of the heart muscle (see also 32). However, a significantly higher $\mathrm{E}^{\prime} / \mathrm{A}^{\prime}$ ratio was found in patients cured by surgery when compared with those well-controlled with long-term octreotide. Furthermore, Sicolo et al. (33) showed that in the presence of diastolic impairment the incomplete recovery of an adequate preload can affect systolic parameters during physical effort. Since systolic function was only measured at rest, it is possible that systolic function could still be impaired on effort and hence there might be a difference between those cured and those in remission. Therefore, these data suggest that acromegalic patients, well controlled according to stringent criteria, still reveal biological effects of slight $\mathrm{GH}$ overproduction. In accordance, there are indications that treatment of active acromegaly with somatostatin analogues resulting in normal IGF-I and $\mathrm{GH}$ levels does not completely normalize $\mathrm{GH}$ secretion. Recently, we investigated 24 -h GH profiles in uncontrolled and well-controlled acromegaly patients, treated with long-acting somatostatin analogues (34). We applied the same strict biochemical criteria for wellcontrolled disease (normal IGF-I levels and a GH profile during 24-h GH sampling of $<2.5 \mu \mathrm{g} / \mathrm{l}$ ) in both groups. However, GH was actually sporadically below $0.5 \mu \mathrm{g} / \mathrm{l}$, although chronic treatment with somatostatin analogues repressed amplitude-dependent measures of excessive GH secretion in acromegaly. Moreover, tumoral endocrine autonomy was inferred by continued elevations of event frequency, overall pattern disruption (irregularity), and nonsuppressible basal GH secretion. We postulate that these subtle abnormalities in $\mathrm{GH}$ secretion relate to the persistently impaired diastolic function despite clinically normal GH and IGF-I levels.

In conclusion, long-term control of GH/IGF-I excess is associated with normal LV mass and LV dimensions. Nonetheless, diastolic function is more impaired in well-controlled patients than in surgically cured patients, which proves that the current criteria for strict biochemical control of acromegaly may still be associated with subtle effects of excessive GH secretion. Although the clinical relevance of this observation remains to be determined, these patients might benefit from more agressive control of $\mathrm{GH}$ production than obtained by applying the current 'strict' criteria of biochemical control of GH excess.

\section{References}

1 Vitale G, Pivonello R, Galderisi M, D’Errico A, Spinelli L, Lupoli G, Lombardi G \& Colao A. Cardiovascular complications in acromegaly: methods of assessment. Pituitary 2001 4 251-257.

2 Colao A, Marzullo P, Di Somma C \& Lombardi G. Growth hormone and the heart. Clinical Endocrinology 200154 137-154.

3 Lombardi G, Colao A, Marzullo P, Ferone D, Longobardi S, Esposito V \& Merola B. Is growth hormone bad for your heart? Cardiovascular impact of GH deficiency and of acromegaly. Journal of Endocrinology 1997155 (Suppl 1) S33-S37.

4 Clayton RN. Cardiovascular function in acromegaly. Endocrine Reviews $200324272-277$.

5 Sacca L, Napoli R \& Cittadini A. Growth hormone, acromegaly, and heart failure: an intricate triangulation. Clinical Endocrinology $200359660-671$.

6 Pereira AM, van Thiel SW, Lindner JR, Roelfsema F, van der Wall EE, Morreau H, Smit JW, Romijn JA \& Bax JJ. Increased prevalence of regurgitant valvular heart disease in acromegaly. Journal of Clinical Endocrinology and Metabolism 200489 71-75.

7 Colao A, Spinelli L, Marzullo P, Pivonello R, Petretta M, Di Somma C, Vitale G, Bonaduce D \& Lombardi G. High prevalence of cardiac valve disease in acromegaly: an observational, analytical, case-control study. Journal of Clinical Endocrinology and Metabolism $2003 \mathbf{8 8} 3196-3201$.

8 Colao A, Cuocolo A, Marzullo P, Nicolai E, Ferone D, Della Morte AM, Petretta M, Salvatore M \& Lombardi G. Impact of patient's age and disease duration on cardiac performance in acromegaly: a radionuclide angiography study. Journal of Clinical Endocrinology and Metabolism 199984 1518-1523.

9 Coalo A, Spinelli L, Cuocolo A, Spiezia S, Pivonello R, di Somma C, Bonaduce D, Salvatore M \& Lombardi G. Cardiovascular consequences of early-onset growth hormone excess. Journal of Clinical Endocrinology and Metabolism 200287 3097-3104.

10 Minniti G, Jaffrain-Rea ML, Moroni C, Baldelli R, Ferretti E, Cassone R, Gulino A \& Tamburrano G. Echocardiographic evidence for a direct effect of GH/IGF-I hypersecretion on cardiac mass and function in young acromegalics. Clinical Endocrinology $199849101-106$.

11 Fazio S, Cittadini A, Biondi B, Palmieri EA, Riccio G, Bone F, Oliviero U \& Sacca L. Cardiovascular effects of short-term growth hormone hypersecretion. Journal of Clinical Endocrinology and Metabolism $2000 \mathbf{8 5} 179-182$. 
12 Kahaly G, Olshausen KV, Mohr-Kahaly S, Erbel R, Boor S, Beyer J \& Meyer J. Arrhythmia profile in acromegaly. European Heart Journal $19921351-56$.

13 Colao A, Cuocolo A, Marzullo P, Nicolai E, Ferone D, Della Morte AM, Pivonello R, Salvatore M \& Lombardi G. Is the acromegalic cardiomyopathy reversible? Effect of 5-year normalization of growth hormone and insulin-like growth factor I levels on cardiac performance. Journal of Clinical Endocrinology and Metabolism $2001861551-1557$.

14 Biermasz NR, Pereira AM, Frolich M, Romijn JA, Veldhuis JD \& Roelfsema F. Octreotide represses secretory-burst mass and nonpulsatile secretion but does not restore event frequency or orderly GH secretion in acromegaly. American Journal of Physiology Endocrinology and Metabolism 2004286 E2 5-E30.

15 Dimaraki EV, Jaffe CA, DeMott-Friberg R, Chandler WF \& Barkan AL. Acromegaly with apparently normal GH secretion: implications for diagnosis and follow-up. Journal of Clinical Endocrinology and Metabolism 200287 3537-3542.

16 Biermasz NR, van den Oever NC, Frolich M, Pereira AM, Smit JW, Romijn JA \& Roelfsema F. Sandostatin LAR in acromegaly: a 6week injection interval suppresses GH secretion as effectively as a 4-week interval. Clinical Endocrinology 200358 288-295.

17 Sohn DW, Chai IH, Lee DJ, Kim HC, Kim HS, Oh BH, Lee MM, Park YB, Choi YS, Seo JD \& Lee YW. Assessment of mitral annulus velocity by Doppler tissue imaging in the evaluation of left ventricular diastolic function. Journal of the American College of Cardiology $199730474-480$.

18 Hradec J, Marek J, Kral J, Janota T, Poloniecki J \& Malik M. Longterm echocardiographic follow-up of acromegalic heart disease. American Journal of Cardiology 199372 205-210.

19 Devereux RB, Alonso DR, Lutas EM, Gottlieb GJ, Campo E, Sachs I \& Reichek N. Echocardiographic assessment of left ventricular hypertrophy: comparison to necropsy findings. American Journal of Cardiology 198657 450-458.

20 Park SH, Shub C, Nobrega TP, Bailey KR \& Seward JB. Twodimensional echocardiographic calculation of left ventricular mass as recommended by the American Society of Echocardiography: correlation with autopsy and M-mode echocardiography. Journal of the American Society of Echocardiography 19969 119-128.

21 Colao A, Marzullo P, Ferone D, Spinelli L, Cuocolo A, Bonaduce D. Salvatore M, Boerlin V, Lancranjan I \& Lombardi G. Cardiovascular effects of depot long-acting somatostatin analog Sandostatin LAR in acromegaly. Journal of Clinical Endocrinology and Metabolism $2000 \mathbf{8 5} 3132-3140$.

22 Gilbert J, Ketchen M, Kane P, Mason T, Baister E, Monaghan M, Barr S \& Harris PE. The treatment of untreated acromegalic patients with octreotide-LAR: efficacy, tolerability and cardiovascular effects. Pituitary $2003611-18$.

23 Hradec J, Kral J, Janota T, Krsek M, Hana V, Marek J \& Malik M. Regression of acromegalic left ventricular hypertrophy after lanreotide (a slow-release somatostatin analog). American Journal of Cardiology 199983 1506-1509 A8.

24 Colao A, Cuocolo A, Marzullo P, Nicolai E, Ferone D, Florimonte L, Salvatore M \& Lombardi G. Effects of 1-year treatment with octreotide on cardiac performance in patients with acromegaly. Journal of Clinical Endocrinology and Metabolism $1999 \mathbf{8 4}$ $17-23$.

25 Merola B, Cittadini A, Colao A, Ferone D, Fazio S, Sabatini D, Biondi B, Sacca L \& Lombardi G. Chronic treatment with the somatostatin analog octreotide improves cardiac abnormalities in acromegaly. Journal of Clinical Endocrinology and Metabolism $199377790-793$.

26 Thuesen L, Christensen SE, Weeke J, Orskov H \& Henningsen P. The cardiovascular effects of octreotide treatment in acromegaly: an echocardiographic study. Clinical Endocrinology 198930 619-625.

27 Tokgozoglu SL, Erbas T, Aytemir K, Akalin S, Kes S \& Oram E. Effects of octreotide on left ventricular mass in acromegaly. American Journal of Cardiology 199474 1072-1074.
28 Lim MJ, Barkan AL \& Buda AJ. Rapid reduction of left ventricular hypertrophy in acromegaly after suppression of growth hormone hypersecretion. Annals of Internal Medicine 1992117 719-726.

29 Pereira JL, Rodriguez-Puras MJ, Leal-Cerro A, Martinez A, GarciaLuna PP, Gavilan I, Pumar A \& Astorga R. Acromegalic cardiopathy improves after treatment with increasing doses of octreotide. Journal of Endocrinological Investigation 199114 17-23.

30 Melmed S. Acromegaly and cancer: not a problem? Journal of Clinical Endocrinology and Metabolism $2001862929-2934$.

31 Biermasz NR, Dekker FW, Pereira AM, van Thiel SW, Schutte PJ, van Dulken H, Romijn JA \& Roelfsema F. Determinants of survival in treated acromegaly in a single center: predictive value of serial insulin-like growth factor I measurements. Journal of Clinical Endocrinology and Metabolism $2004892789-2796$.

32 Sacca L, Cittadini A \& Fazio S. Growth hormone and the heart. Endocrine Reviews 199415 555-573.

33 Sicolo N, Bui F, Sicolo M, Varotto L, Martini C, Macor C \& Federspil G. Acromegalic cardiopathy: a left ventricular scintigraphic study. Journal of Endocrinological Investigation $1993 \mathbf{1 6} 123-127$.

34 van Thiel SW, Romijn JA, Biermasz NR, Ballieux BE, Frolich M, Smit JW, Corssmit EP, Roelfsema F \& Pereira AM. Octreotide long-acting repeatable and lanreotide Autogel are equally effective in controlling growth hormone secretion in acromegalic patients. European Journal of Endocrinology 2004150 489-495.

35 Chanson P, Boerlin V, Ajzenberg C, Bachelot Y, Benito P, Bringer J, Caron P, Charbonnel B, Cortet C, Delemer B, Escobar-Jiminez F, Foubert L, Gaztambide S, Jockenhoevett, Kuhn JM, Leclere J, Lorcy Y, Perlemuter L, Prestele H, Roger P, Rohmer V, Santen R, Sassolas G, Scherbaum WA, Schoapohl J, Torres E, Varela C, Villamil F \& Webb SM. Comparison of octreotide acetate LAR and lanreotide SR in patients with acromegaly. Clinical Endocrinology $2000 \mathbf{5 3} 577-586$.

36 Baldelli R, Ferretti E, Jaffrain-Rea ML, Iacobellis G, Minniti G, Caracciolo B, Moroni C, Cassone R, Gulino A \& Tamburrano G. Cardiac effects of slow-release lanreotide, a slow-release somatostatin analog, in acromegalic patients. Journal of Clinical Endocrinology and Metabolism $1999 \mathbf{8 4} 527-532$.

37 Minniti G, Moroni C, Jaffrain-Rea ML, Esposito V, Santoro A, Affricano C, Cantore G, Tamburrano G \& Cassone R. Marked improvement in cardiovascular function after successful transsphenoidal surgery in acromegalic patients. Clinical Endocrinology $200155307-313$.

38 Herrmann BL, Bruch C, Saller B, Bartel T, Ferdin S, Erbel R \& Mann K. Acromegaly: evidence for a direct relation between disease activity and cardiac dysfunction in patients without ventricular hypertrophy. Clinical Endocrinology 200256 595-602.

39 Vianna CB, Vieira ML, Mady C, Liberman B, Durazzo AE, Knoepfelmacher M, Salgado LR \& Ramires JA. Treatment of acromegaly improves myocardial abnormalities. American Heart Journal $2002143873-876$.

40 Lombardi G, Colao A, Marzullo P, Biondi B, Palmieri E \& Fazio S. Improvement of left ventricular hypertrophy and arrhythmias after lanreotide-induced GH and IGF-I decrease in acromegaly. A prospective multi-center study. Journal of Endocrinological Investigation $200225971-976$.

41 Colao A, Marzullo P, Cuocolo A, Spinelli L, Pivonello R, Bonaduce D, Salvatore M \& Lombardi G. Reversal of acromegalic cardiomyopathy in young but not in middle-aged patients after 12 months of treatment with the depot long-acting somatostatin analogue octreotide. Clinical Endocrinology 2003 58 169-176.

42 Ciulla MM, Epaminonda P, Paliotti R, Barelli MV, Ronchi C, Cappiello V, Sartorio A, Buonamici V, Magrini F, Beck-Peccoz P \& Arosio M. Evaluation of cardiac structure by echoreflectivity analysis in acromegaly: effects of treatment. European Journal of Endocrinology 2004151 179-186.

Received 2 February 2005

Accepted 3 May 2005 